\title{
A Speech Planning Account of Guarani Grammatical Borrowings in Paraguayan Spanish
}

\author{
Bruno Estigarribia \\ Associate Professor of Spanish, Department of Romance Studies, \\ University of North Carolina at Chapel Hill, Chapel Hill, USA \\ estigarr@email.unc.edu
}

\begin{abstract}
Previous studies view the use of Guarani grammatical morphemes in Paraguayan Spanish simply as grammatical borrowings (if one focuses on the morphosyntactic status of mixed forms) or as an ill-defined "interference". But so far there has been no examination of the bilingual planning mechanisms that license and constrain these language mixes. In this paper, I explore the idea that the emergence of grammatical borrowings can be explained by message conceptualization procedures that are influenced by asymmetries in each language's cognitive dominance. This work thus contributes to our understanding of language contact by applying what we know about language processing and utterance planning to explaining the outcomes observed in language mixing. In so doing, I hope to facilitate a tighter integration between the psycholinguistic planning and language contact literatures.
\end{abstract}

\section{Keywords}

loanwords - code-mixing - code-switching - language dominance - speech planning Jopara

\section{Introduction}

In this contribution, I report on the use of Guarani grammatical morphemes in Paraguayan Spanish. Previous studies have assumed that these uses result from interference or grammatical borrowing (Usher de Herreros, 1976; Granda, 198o, 1996; Krivoshein de Canese and Corvalán, 1987; Penner, Acosta and Segovia, 
2012). However, this type of mixing has rarely been studied from the perspective of contemporary theories of language contact and its mechanisms and effects (but see Gómez Rendón, 2008; Estigarribia, 2017a). In (1), we see that Guarani interrogative (a), emphatic (b), and imperative modalizing particles (c) are used in Spanish with their original Guarani form and meaning (see Estigarribia, $2017 \mathrm{~b}, 2020$ for fuller descriptions of these morphemes). ${ }^{1}$

(1a) Guarani interrogative second-position clitics:

¿Entendite, pa?

entendiste $=\mathbf{p a}$

understood.2SG $=\mathrm{Q}$

'Did you understand?' (Granda, 1980: 62)

(1b) Guarani emphatic second-position clitics (veridical and assertive): Así co é la vida.

así=ko es la vida

Thus=VERD is the life

'But that's life.' (Granda, 1980: 63)

(1c) Guarani imperative modalizing affixes:

Venína un poco.

vení-na un poco

come.2SG-IMP.REQ a little

'Come for a second, please.' (Krivoshein de Canese \& Corvalán, 1987: 46)

These data raise interesting questions about the mechanisms that underlie grammatical borrowings and the existence of constraints on these mechanisms. On the one hand, from a morphological standpoint, none of these particles are free morphemes: they are clausal (second position) clitics or affixes, all of which are supposed to be of relatively low borrowability (Matras, 2007). On the other hand, from a semantic/pragmatic standpoint the interrogative and emphatic particles are akin to discourse markers, which have

1 I follow the Leipzig Glossing Rules (https://www.eva.mpg.de/lingua/resources/glossing-rules. php; accessed 20 May 2020). I will use boldface for Guarani morphemes, and light typeface for Spanish morphemes. 
relatively high borrowability. ${ }^{2}$ A common explanation for the borrowability of discourse markers is that they are relatively independent syntactically. Yet, it is not clear how to measure this independence. For example, interrogative particles or imperative modalizing suffixes are rather tightly integrated in the syntax of the clause: they are not peripheral in a morphosyntactic sense, again relatively disfavoring borrowing. At the same time, Guarani being an agglutinative language, what all markers seem to have in common is a relatively high salience and a relatively invariant form, both of which can facilitate borrowing.

Moreover, what makes these Guarani borrowings unique is that in the more common contact scenario it is discourse markers from Spanish that are borrowed into the indigenous language (e.g., Quechua, Aymara, Náhuatl), but here the converse has happened. The question is, of course, why.

In this paper, I will attempt to integrate these data into our recent understanding of the effects and mechanisms of language contact. Specifically, I will explore the idea that these borrowings are best seen as the result of specifically bilingual sentence planning procedures. ${ }^{3}$ I will argue that these occurrences can be explained by message conceptualization procedures that are heavily influenced by asymmetries in the cognitive dominance of each language. Because of the particular situation of Guarani and Spanish, in this case it is the indigenous language that influences the colonizing language. Finally, in proposing this explanation, I hope to move towards a tighter integration between the psycholinguistic planning and language contact literatures.

\section{A Long History of Intensive Contact: Guarani, Spanish, and Jopara}

Prior to colonization by the Spanish and the Portuguese, Tupi-Guarani groups (speaking closely related Tupi-Guarani languages) occupied a vast territory south of the Amazon, roughly demarcated by the source of the Paraguay river in the north (Alto Paraguay, near present-day Cuiabá and Diamantino in Brazil's Mato Grosso state), the Paraná islands in the south, the Paraguay River in the west, and the (now Brazilian) coast in the East (Corvalán, 199o; Velázquez-Castillo, 2004). These Tupi-Guarani groups mostly settled alongside

2 We can call them, with Backus and Verschik (2012: 140), discourse pragmatic words, that is "discourse markers, focus and modal particles, interjections, phrasal adverbs and conjunctions."

3 Even though I use the term bilingual here, the processes I hypothesize should also occur in multilingual cases more generally. 
the rivers Paraguay, Paraná and Uruguay, with the Tupi groups north of the Paranapanema river, and the Guarani groups south of it (Palacios Alcaine, 1999). Different Guarani subgroups were found in the future territory of the Spanish Paraguay Province. Specifically, the Carios occupied what is now the Asunción area, with the Tobati, Mbarakaju, Guarambare, and Itati to the north along the left bank of the Paraguay river, the Guayra to the northeast and east along the right bank of the Parana river between the Paranapanema and the Iguasu, the Tape to the southeast, east of the Uruguay river in present-day Serra Geral (Rio Grande do Sul), the Parana to the south along the Parana river, the Chiriguano and the Guarayo near the Andean mountains in the west (present-day Santa Cruz de la Sierra Province, in Bolivia), and the southernmost Chandules in the islands of the Parana delta (Corvalán, 199o; Palacios Alcaine, 1999).

The history of contact between Guarani and Spanish is very long. It began in the first half of the 16th century with a series of Spanish incursions along the Paraná and Paraguay river basins that culminated with the foundation of Fuerte de Nuestra Señora de la Candelaria (near present-day Fuerte Olimpo) by Juan de Ayolas in February 1537 and Nuestra Señora Santa María de la Asunción (today, Asunción) in August 1537. The initial number of Spaniards who occupied the area that is now Paraguay was very small. What's more, the region never benefitted from a continuous influx of colonists (Zajícová, 2009). Gómez Rendón (2017) estimates that only around 1000 Spanish immigrants settled in the region during the 16th century, mostly males, with around 50 females. Most Spanish males took several Guarani (mostly Cario) concubines during this period, a practice that is widely thought to have favored the miscegenation that made Paraguay an essentially mestizo society already by the second or third generation. The situation did not change significantly during the remainder of the colonial period. Perú had always been the Spanish crown main commerce hub, and it was much more accessible from Panama than Asunción. Then Potosí in the west and Buenos Aires in the east on the Atlantic came into play more as economic routes, leaving Asunción and the surrounding area very marginalized (Kleinpenning, 2011).

Extensive miscegenation is usually considered a crucial factor in both the survival of Guarani and in the outcome of Guarani-Spanish language contact. For one, Spanish settlements became bilingual spaces very quickly, as the mestizo population progressed, since (male) Spanish monolingual speakers were outnumbered by (mostly female) Guarani speakers and by (presumably) bilingual descendants. At the same time, Franciscan-organized Indian Villages where natives lived while they performed labor for Spanish colonizers were 
centers of Guarani language and culture which were very slowly absorbed into the mainstream of Paraguayan population in the nineteenth century (Gómez Rendón, 2017).

However, it would be a mistake to believe that Guarani survived colonization unscathed. In fact, Spanish-Guarani language mixing was pervasive throughout these centuries and today, "pure", un-hispanicized Guarani (often called Guaraniete, 'authentic, true Guarani') is unlikely to exist. Most Paraguayans communicate in a mixed code called Jopara ('mixed'), described by Estigarribia (2015) as a mixed lect composed of a continuum of varieties ranging from mostly Guarani discourse with Spanish borrowings/switches ("Guarañol" is Melià's, 1986: 244, term; see 2) to mostly Spanish discourse with Guarani borrowings/switches (“Castení", Gómez Rendón’s, 2008: 209, term; ex. 3).

(2) Ndovaléi reluchá nde sentimientore.

$\begin{array}{lll}\text { Nd-o-valé-i } & \text { re-luchá } & \text { nde-sentimiento=re. } \\ \text { NEG-3ACT-be.worth-NEG } & \text { 2SG.ACT-fight } & \text { 2SG.INACT-feeling=LOC }\end{array}$ 'It is not worth it to fight against your feelings.' (Ayala de Michelagnoli, 1989:30)

(3) Eso katu e lo que yo etá queriendo, hína.

Eso katu es lo que yo está queriendo, hína.
That just is that which

'That is just what I want.' (Ayala de Michelagnoli, 1989: 29)

Jopara is thus similar to Mexicano (Torres, 2006; see also Hill and Hill, 1986), a mixed code that is a continuum of productions between two poles, a purist code close to Náhuatl without Spanish influence and a "power code" which is heavily influenced by Spanish. Spanish is the public language, whereas Mexicano is used in the private and ritual spheres and has the associated affect of being the community language. Importantly, Mexicano includes Spanish discourse markers with some degree of loss of the original grammatical meanings and range of function, and which do not fill a gap in Náhuatl, which has its own discourse marker system. "Guarañol" Jopara also shows borrowed Spanish discourse markers. However, unlike in the documented cases of discourse marker borrowing from a colonizer language into an indigenous language, "Castení" Jopara conversely includes Guarani (indigenous language) markers used in Spanish (colonizer language) discourse. 


\subsection{The Corpora}

My main data source for Colloquial Paraguayan with Guarani mixing is the Paraguayan film Siete Cajas (Maneglia and Schembori, 2014). This is the story of a pushcart porter, Víctor, in the Mercado 4 (Market number four) in Asunción. Víctor is in search of money to buy a cellphone with videocamera. He is approached with a proposal to transport seven boxes of unknown contents in exchange for an important sum. He then becomes unwittingly involved in a serious crime. The film is of tremendous linguistic importance because most of it takes place in Jopara, exemplifying the complex relations that determine the choice of code between colloquial Paraguayan Spanish and Spoken Guarani. For this paper, I focus solely on the dialogues in colloquial Spanish that include Guarani particles. Another occasional source of examples is the first novel written entirely in Jopara: Ramona Quebranto (Ayala de Michelagnoli, 1989).

When necessary, I supplement this source of data with social media data, which has the advantage of being naturalistic (produced spontaneously in a real interaction in a typical communicative setting, as opposed to rehearsed or elicited). I culled examples from the Facebook page Paraguay Oficial (https:// www.facebook.com/ParaguayOficial), the Facebook feed for the Paraguayan newspaper ABC, the Revista Arsenio Erico (http://www.revistaarsenioerico. com, a digital newspaper from the Paraguayan community in New York), and the comment threads from the page of Paraguay's Diario Popular (http://archivos.hoy.com.py). I furthermore looked for examples in a Paraguayan forum about cars called Motores.com.py (http://motores.com.py/foro) and in a general forum for Paraguayans, La Jaula (http://www.lajaula.com.py/foro). Finally, I looked extensively at posts and comments from the blog nderasore.com, a personal blog with jokes, viral content, and memes. ${ }^{4}$

\subsection{The Morphemes}

The morphemes studied here satisfy the following criteria: (1) they are bound morphemes, either clitics or affixes, chosen because these are a priori harder to borrow than free morphemes; (2) they have different degrees of syntactic integration in the clause, chosen to allow us to determine whether syntactic integration makes a difference in the frequencies of occurrence; (3) and they make different semantic or pragmatic contributions to the clause, allowing us

4 Last accessed 20 September 2017. The domain has expired and is not accessible at the moment of publication of this study. 
to determine whether grammatical (semantic) meaning or use make a difference in mixed usage. None of the Guarani morphemes presented in this section have Spanish equivalents, but some other morphemes do. This distinction will be important in the discussion in sections 5 and 6 .

\subsubsection{Guarani Interrogative Markers}

In Guarani, questions have the same intonation and word order as declaratives. They are not marked by special prosody or constituent reordering, but by interrogative markers, the most common being $=p a$ and $=p i k o$. These markers are second position clitics, that is, they are phonologically dependent on the first major clausal constituent which is their host, as shown in (4) below (Ayala, 1996; Estigarribia, 2017b, 2020). Guarani interrogative markers are used in Spanish yes/no questions, wh-questions, and in embedded questions $\left(5^{-10}\right) .^{5}$

(4) Susana ha Évapa opytu'u.

$\begin{array}{llll}\text { Susana } & \text { ha } & \text { Éva }]=\text { pa } & \text { o-pytu'u } \\ \text { Susana } & \text { and } & \text { Eva }=Q & \text { 3.ACT-rest }\end{array}$

'Are Susana and Eva resting?' (Ortiz, Aguilera and Marecos, 1991: 14)

(5) no tenes pio nada de ideas para esto?

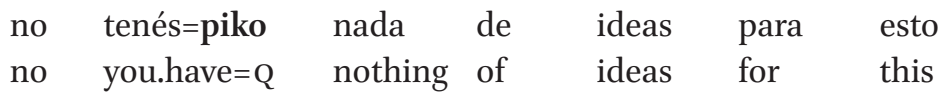

'You don't have any ideas for this?' (http://nderasore.com/1987/12/1987/, Marcelo, July 11, 2011)

(6) ¿E cierto pa que Julio e tu novio?

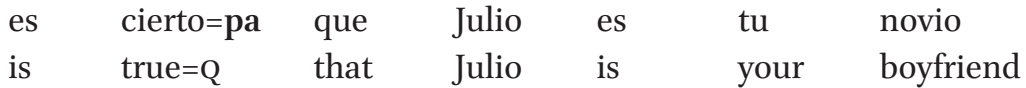

'Is it true that Julio is your boyfriend?'

(Ayala de Michelagnoli, 1989:16)

5 I identify examples from Siete Cajas as [7C], and I give links for the examples from social media. Examples from social media are first given exactly as found on the web. I added a "normalized" rendering in a second line, taking into account the modern accepted orthography of Guarani, modified to represent accurately the linguistic status of attached morphemes (see Estigarribia, 2017b). Examples from Siete Cajas are given in the "normalized" rendering. 
(7) Q estupido, como pío le va a patear??

Qué estúpido, cómo=piko le va a patear what stupid how $=\mathrm{Q}$ to.him goes to kick 'What an idiot, why on earth did he kick him?' (https://www.facebook. com/ParaguayOficial, Ross Saucedo, September 21, 2014)

(8) Sólo queremo sabé si vive o se murió pa.

sólo queremos saber si vive o se murió=pa
only we.want know if lives or SE died $=Q$

'All we want to know is if he is alive or dead.'

(Ayala de Michelagnoli, 1989: 23)

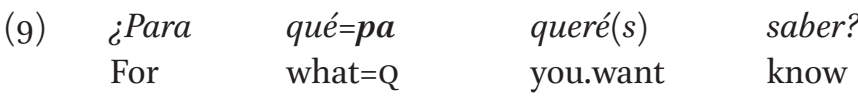

'Why do you want to know?'[7C]

(10) ¿No querés=pi(k)o que te pase a buscar...? No you.want $=\mathrm{Q}$ that to.you I.pass to seek

'Don't you want me to come get you...?' [ $\left.{ }_{7} \mathrm{C}\right]$

The spoken data from Siete Cajas reveal that the interrogative markers are not strictly necessary to mark these sentences as questions in Paraguayan Spanish, because Spanish question intonation, and for wh-questions also question markers, are sometimes already present. The Guarani interrogative markers thus "double" the Spanish interrogative marking. ${ }^{6}$

$\begin{array}{lll}¿ Q u e ́ r=p a & \text { es } & \text { eso } \searrow \text { ? } \\ \text { what }=\mathrm{Q} & \text { is } & \text { that } \\ \text { 'What is that?' }\left[{ }_{7} \mathrm{C}\right] & & \end{array}$

(12) ¿No ve(s)=pikor que e(s) con filmadorar y to(do)\? no you.see $=Q$ that is with videocamera and all 'Don't you see that it even has a videocamera?' $[7 \mathrm{C}]$

6 There is true morphological doubling in wh-questions, and "quasi-doubling" of intonation with morphology in yes/no questions. There may be a difference in frequency of borrowing between the two, but it is not supported by the Siete Cajas data, which includes 24 yes/no questions and 23 wh-questions with Guarani interrogative clitics. (I thank Nikolay Hakimov for raising this issue.) 
(13) ¿Para qué $=p i(k)$ o queré $(s) \quad$ saber $\searrow$ ? for what $=\mathrm{Q}$ you.want know

'Why do you want to know?' [7C]

(14) ¿Entendiste $\nearrow=p a \searrow$ ?

you.understood $=\mathrm{Q}$

'Did you understand?' [ $\left.{ }_{7} \mathrm{C}\right]$

\subsubsection{Guarani Emphatic Marker}

Similarly, Guarani has a number of evidential or attitudinal morphemes. One of the most frequent is the second position clitic that surfaces as =niko (often nio), =ko, =ningo or =ngo. Niko is a marker of truthful narrative mood (Guarania, 2008: 40) and emphasis (Ayala, 1996; see also Tonhauser, 2006 and Velázquez-Castillo, 2004, 2008). I gloss it here as VERD (veridical) following Estigarribia (2020). Spanish, on the other hand, has no morphologized set of emphatic or attitudinal markers.

(15) Kuehe niko omba'apo gueteri.

kuehe $=$ niko

o-mba'apo

gueteri

yesterday $=$ VERD

3.ACT-work still

'Yesterday, yes, he still worked.' (Guarania, 2008: 40)

The Guarani emphatic marker $=(n i) k o$ also occurs in our data, in all its diverse allomorphs, phonologically attached to a variety of categories.

(16) no me hace niko falta.

$\begin{array}{llll}\text { no } & \text { me } & \text { hace=niko } & \text { falta } \\ \text { no } & \text { me } & \text { makes=VERD } & \text { miss }\end{array}$

'but I don't need him.' (Ayala de Michelagnoli, 1989:16)

(17) ellango e tu amiga

ella=ngo $\quad$ es $\quad$ tu $\quad$ amiga

'but she is your friend' (Ayala de Michelagnoli, 1989: 90) 
(18) cuando alguien está siendo electrocutado nio no podes tocarle!! cuando alguien está siendo electrocutado=niko no when someone is being electrocuted=VERD no podés tocarle you.can touch.him

'When someone is being electrocuted you cannot touch them!' (https://www.facebook.com/ParaguayOficial; Ross Saucedo September 21, 2014 at 10:36pm)

(19) A quien sea $=$ ngo le tengo que vende( $r$ ) ese A who be.SBJV=VERD to.him I.have that sell that.one 'But I must sell that to whoever' $[7 \mathrm{C}]$

\subsubsection{Guarani Imperative Modalizing Suffixes}

The basic imperative mood is conveyed in Guarani via the verb prefix $e$ - for 2SG and pe-for $2 \mathrm{PL}^{7}{ }^{7}$ This basic imperative is supplemented by a system of suffixes that attach to the predicate to convey different degrees of imperative meaning, what I call imperative modalizing affixes here: the forceful imperative $-k e$ (glossed FORCE), the requestative -na (REQ), which conveys a polite, somewhat mitigated request, the pleading imperative -mi (MIT), which is mitigative with affectionate nuances, and the urging imperative -py (URG), which is used to incite somebody to action or when an order must be repeated (Guarania, 2008; Zarratea, 2002).

(20a) Emba'apóke

E-mba'apo-ke

IMP.2SG-work-FORCE

'Work (I command you to)'

(21b) Emba'apóna nde

$\begin{array}{ll}\text { E-mba'apo-na } & \text { nde } \\ \text { IMP.2SG-work-REQ } & \text { 2SG } \\ \text { 'You work, please' } & \end{array}$

7 This is true only for "active" roots; for inactive roots the imperative is the same as the indicative form (see Estigarribia, 2017b). 
(21c) Emba'apomi

E-mba'apo-mi

IMP.2SG-work-MIT

'I beg you to work'17 (Krivoshein de Canese and Acosta Alcaraz, 2007: 100)

(21d) Eguatapy

E-guata-py

IMP.2SG-walk-URG

'Walk then!' (Zarratea, 2002: 124)

All of these imperative suffixes occur in colloquial Paraguayan Spanish, attached to the Spanish imperative verb forms.

(21) ... que caminána así, que bañáteke.

que caminá-na así que bañáte-ke

that walk-REQ thus that take.a.bath-FORCE

'...walk this way, take a bath.' (Ayala de Michelagnoli, 1989: 33)

(22) Tomameque el jugo y come la ensalada

Tomame-ke el jugo y comé la ensalada

Drink.IMP.me-ForCE the juice and eat.ImP the salad 'Drink the juice and eat the salad' (http://nderasore.com/2012/o1/ los-castigos-de-antes-eran-de-la-pesada/)

(23) papa eso es en Argentina, leeeeeeeeeeeeeeeeeeeeeeeeeeena lo que puseeeeeeeeeeeeeeee

papá eso es en Argentina lee-na lo que puse dad that is in Argentina read.IMP-REQ it that I.put 'Dude, that's in Argentina, please read what I wrote' (http://motores. com.py/foro/index.php?threads/que-sienten-cuando-adelantan-un-camion-enorme-y-ademas-largooo.39305/page-9, enzomas, 5 Feb 2013)

(24) pone py la foto de tu corolla...

poné-py la foto de tu Corolla put.IMP-URG the photo of your Corolla 'Upload the pic of your Corolla already...' (http://motores.com.py/ foro/index.php?threads/que-sienten-cuando-adelantan-un-camion-enorme-y-ademas-largooo.39305/page-3, fabioa, 7 Dic 2012) 

(25)
bien
ne-mita- $\tilde{\imath}$
pay.attention.to.me.IMP-FORCE well
2SG.INACT-child-DIM
'Pay close attention to me, child.' [7C]

There are no uses where the basic Guarani imperative prefix $e$ - co-occurs with the Guarani imperative suffixes (26). However, this usage is attested in the novel Ramona Quebranto.

(26) Si no podé cambiá de problema, ecambiamína de hombre

Si no podés cambiar de problema, e-cambia-mí-na

if no you.can change of problem IMP.2SG-change.IMP-MIT-REQ

de hombre

of man

'If you cannot trade problems, trade men.' (Ayala de Michelagnoli, 1989: 26)

\subsubsection{Frequencies of Occurrence}

Observed frequencies of occurrence of different morphemes often figure in discussions of borrowing. Albeit very useful, the interpretation of observed frequency information is not without pitfalls.

In Siete Cajas, I found a total of 107 occurrences of Guarani bound markers in Spanish sentences. Of those 47 are uses of interrogative $=p a /=p i k o(\approx 44 \%$ of all switched Guarani bound morphemes), 29 of imperative -ke/-na/-kena ( $\approx 27 \%)$, and 27 of emphatic $=k o /=n i k o(\approx 25 \%)$. Other morphemes account for under $4 \%$ of cases. The full distribution of bound morphemes is given in Table 1.

However, one must note that, in any given corpus, the frequencies observed are a function of (a) how frequent the meaning they express is, and (b) how frequently the morphemes express that meaning (i.e., whether the marker is obligatory for that meaning, optional but common, or rare). For example, it could simply be that uses of interrogative markers are more common than uses of diminutive markers just because questions are more common than contexts where a diminutive would be expressed. In order to control for that, one can calculate conditional probabilities, that is, what the probability is that a Guarani element will appear, given a Spanish sentence in which the requisite meaning must be expressed by the speaker. This is a difficult calculation to make from a corpus, however, because for many meanings in the pragmatic realm it is difficult or impossible to identify the contexts in which a given meaning must be expressed. What we can do is take all cases where a given meaning is expressed either with a Guarani or with a Spanish morpheme and calculate 
TABLE 1 Token counts of Guarani bound morphemes in Spanish and percentages over the total number of occurrences in Siete Cajas

\begin{tabular}{lcc}
\hline & Tokens & $\%$ \\
\hline Interrogative =pa, =piko & 47 & 44 \\
Imperative modalizing =ke, =na, =kena & 29 & 27 \\
Emphatic veridical =ko, =niko & 27 & 25 \\
Intensifier - $e t e$ ('very') & 1 & $<1$ \\
Aspectual - $m a$ ('already') & 1 & $<1$ \\
Locative =pe ('in', 'on', 'at') & 1 & $<1$ \\
1sg possessive che- & 1 & 100 \\
\hline TOTAL & 107 & \\
\hline
\end{tabular}

the percentage of times that the morpheme comes from Guarani given that subset of sentences. For example, we can take all questions from Siete Cajas that have Spanish as matrix language and calculate what percentage contains a Guarani interrogative clitic. Out of 94 questions in Spanish, 44 bear a Guarani interrogative marker whereas 50 do not, that is slightly under half $(47 \%)$. So, the usage of Guarani interrogative markers in colloquial Paraguayan Spanish, albeit extremely noticeable and frequent, is far from being obligatory. In fact, one can even claim that it is relatively infrequent, since it only occurs in half the contexts in which it could appear.

This sort of calculation is helpful, but it fails for markers such as emphatics, because these are not obligatory in declarative sentences in Guarani or Spanish and they have no counterpart in Spanish. Therefore, one cannot easily calculate Spanish contexts where an emphatic marker would be particularly expected. So, how can we use frequency information in an explanatory framework? We can still identify several parameters that are important:

1. How frequent the meaning $\mathrm{m}$ is in Spanish discourse (using probabilistic notation, $\left.P_{S p}(m)\right)$

2. How high the probability in Guarani discourse is that the Guarani form $\mathrm{f}$ will appear to express meaning $\mathrm{m}$ (or in a context $\mathrm{m})\left(P_{G u}(f \mid m)\right)$ (sometimes discretized as obligatoriness vs. optionality)

3. Whether a Spanish form $\mathrm{f}_{\mathrm{Sp}}$ exists that is equivalent to the Guarani form, that is, such that $\mathrm{m}\left(\mathrm{f}_{\mathrm{Sp}}\right) \approx \mathrm{m}\left(\mathrm{f}_{\mathrm{Gu}}\right)$ (categorial equivalence)

Such calculations have, to the best of my knowledge, not been carried out yet in bilingual data sets, at least not for pragmatic meanings. A usage-based 
perspective calls for such analyses, however, as simple frequency counts can only tell us so much about the extent to which a change in progress has propagated.

Nevertheless, high raw frequencies of borrowed grammatical morphemes, like we observed for three of the Guarani markers, also impact future productions by reinforcing certain models of structural organization (i.e., mixed sentences containing a particular morpheme/marker). Thus, the more common a meaning, and the more commonly that meaning is expressed via a mixed sentence, the more likely that mixed sentence type is to become expected and perhaps conventionalized.

\subsubsection{Morphosyntactic Integration and Semantico-Pragmatic Function} Both the relative syntax-independence of clause-peripheral elements and their propositional or utterance-level scope are often cited as increasing their borrowability (notably by Matras, 2007). In Table 2, I provide a cross-classification according to morphosyntactic position (a structural criterion) and semantico-pragmatic function (a communicative criterion). The three most frequently used Guarani morpheme types appear in the first two rows. From this table, we can conclude that observed high frequencies are not directly influenced by morphosyntactic status but they may be by semantico-pragmatic properties, namely, propositional scope. The illocutionary force/speech act markers, the propositional attitude markers, and the diminutive affix as a marker of speaker expressivity have propositional scope in that their contribution affects the whole proposition and lies outside of truth-conditional calculations. Of these, the only infrequent one is the diminutive. The remaining morphemes all have scopes that are narrower than the proposition (the intensifier scopes over the phrase it is attached to, and the nominal markers scope over the noun phrase) and all make truth-conditional contributions.

This is consistent with Matras' (2007) observation that markers that belong to the emotive or interactional/discourse level are more borrowable. Matras (1998) proposes that the pragmatically dominant language - by which he means the language that is granted maximum available cognitive resources, which would be Guarani in this case - exerts pressures on speakers' planning that lead them to use this language's "directing", "situative", "gesturelike" discourse particles in the other, non-pragmatically-dominant language. My data thus support the idea that borrowing of discourse markers or utterance modifiers (to use Matras' term) is more related to their function than to their structural properties (or even the presence of a gap in the recipient language; but 
TABLE 2 Cross-classification of Guarani "grammatical borrowings" by morphosyntactic scope and semantico-pragmatic function

\begin{tabular}{lll}
\hline & Second-position clitics & Word-level affixes \\
\hline $\begin{array}{lll}\text { Illocutionary force/Speech act } \\
\text { Propositional attitude }\end{array}$ & $\begin{array}{l}\text { interrogatives } \\
\text { emphatics }\end{array}$ & imperatives \\
$\begin{array}{l}\text { Speaker expressivity } \\
\text { Speaker evaluation } \\
\text { Nominal temporal deictic }\end{array}$ & & $\begin{array}{l}\text { diminutive } \\
\text { intensifier } \\
\end{array}$ \\
\hline
\end{tabular}

see discussion below). Yet, this observation does not necessarily explain what makes utterance modifiers more attractive. In the next section, I will put forth an explanation in terms of bilingual language processing and production. Bilingual Speech Production

The last 20 years have seen a renewed interest in the seemingly pre-linguistic conceptualization of a linguistic message, perhaps beginning most clearly with Slobin's "thinking for speaking" hypothesis: ${ }^{8}$

"Thinking for speaking" involves picking those characteristics of objects and events that (a) fit some conceptualization of the event, and (b) are readily encodable in the language. I proposed that, in acquiring a native language, the child learns particular ways of thinking for speaking.

Slobin (1996: 76) formulated this hypothesis in the context of L1 acquisition. However, he did extend this hypothesis to the bilingual case (specifically to the L2 learning case) as what he called "first-language thinking in second-language speaking":

I propose that the grammaticized categories that are most susceptible to [source language] influence have something important in common: they cannot be experienced directly in our perceptual, sensorimotor, and practical dealings with the world $[. .$.$] only language requires us$ to categorize events as ongoing or completed, objects as at rest or as at the end point of a trajectory, and so forth. Other categories seem to be

8 For a more comprehensive summary of the history of these ideas, see Jarvis (2011) and especially Jarvis (2007). 
less dependent on purely verbal categorization. (Slobin, 1996: 91; Slobin's emphasis)

For the sake of concreteness in the discussion, in what follows I will assume a simple model for language production based on Levelt (1989) (see Figure 1). Newer, more sophisticated models exist, of course, that can also help put the ideas in this paper on firm psycholinguistic ground. But Levelt's model, while simple, also includes a first step of conceptualization of the message, that is the early selection of concepts and their organization to conceptualize a situation or event, which will be of paramount importance for my argument. The process leading to the production of an utterance begins with the speaker's communicative intention. Now, the speaker can choose to fulfill that intention non-linguistically, in which case I will have no more to say here. But if the speaker chooses to fulfill that intention linguistically, then the conceptualizer module begins the work of generating a preverbal message. This conceptualizing step includes (a) macroplanning procedures by which the speaker decides which speech acts to accomplish and (b) microplanning procedures that include specifying the contents of each speech act, choosing a propositional format, deciding on the accessibility status of referents, and also deciding what perspective to take in the encoding of an event, what is topical and what is focused, and satisfying any other language-specific requirements which are specified by the next level, the formulator. The output of this microplanning step is a preverbal message (or parts thereof, since planning is assumed to be incremental) that is then retrieved by the formulator for grammatical encoding. The importance of this will become clearer in the next section, since due to the interaction between the conceptualizer and the formulator, this preverbal message is already language-specific. Bilingual speakers have, of course, at least partially different systems in place for the formulator (which includes lexicalization, grammatical encoding, and phonological encoding) to the articulation

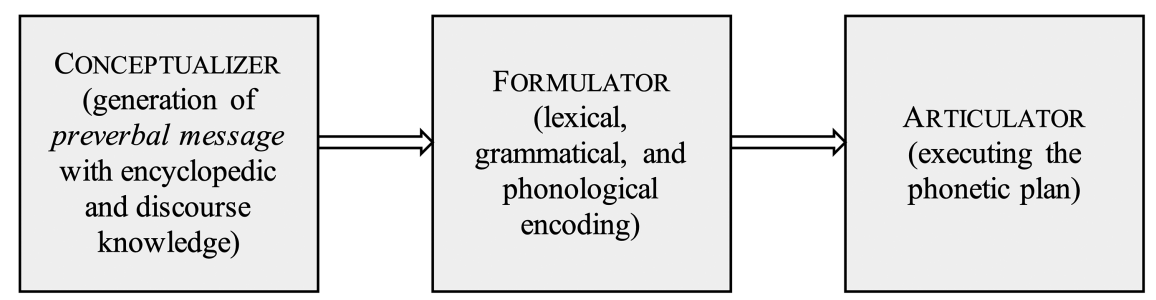

FIGURE 1 A blueprint of processing for language production (simplified from Levelt, 1989: 9) 
phase. ${ }^{9}$ Going back to Slobin, the claim is that there are language-specific ways of structuring content-to-be-conveyed already at the conceptualization stage, prior to any verbalization.

As evidence in favor of this idea, Von Stutterheim and Nüse (2003) specifically pinpoint where in the chain from communicative intention through conceptualization to formulation we can locate language-specific processes. They conclude that language-specific effects are visible already at the macroplanning stage, the stage at which a speaker has formed a communicative intention and is deciding what to say or, rather, what speech acts to accomplish (but see De Bot, 1992: 8, for an argument that language-specificity occurs in microplanning only). A related idea is found in Jarvis' (2007: 44) Conceptual Transfer Hypothesis, that is "the hypothesis that certain instances of crosslinguistic influence in a person's use of one language originate from the conceptual knowledge and patterns of thought that the person has acquired as a speaker of another language." Jarvis distinguishes between two types of conceptual transfer: concept transfer is "[ $\mathrm{t}] \mathrm{ransfer}$ arising from crosslinguistic differences in the conceptual categories stored in L2 users' long-term memory" while conceptualization transfer is "[ $\mathrm{t}] \mathrm{ransfer}$ arising from crosslinguistic differences in the ways L2 users process conceptual knowledge and form temporary representations in their working memory." (ibid.: 53) This author notes as well that (a) these kinds of transfer may occur at the same time and (b) differentiating these two subtypes in given cases of putative conceptual transfer is sometimes difficult.

In an adult L2 learning situation, the expected directionality of these planning-for-speaking or conceptualization effects is for conceptualization in the L1 to affect production in the L2. In order to generalize this expectation to the bilingual case, we adopt the notion of cognitively dominant language at a given point in discourse. This is the language to which bilingual (or multilingual) speakers grant maximum available cognitive resources at a given point in discourse. It may be, often, the language whose units are better entrenched in the speakers' minds and that therefore drive most of the conceptualization in the production of speech, but it need not be, since the cognitively dominant language may change at different points in discourse. It can be influenced, for example, by what Matras (1998) calls pragmatic

9 This is not to say that bilinguals have two separate monolingual systems, as opposed to one "combined" bilingual system. It merely means that the languages a bilingual speaks have monolingual grammar instantiations with different lexica, morphosyntax, phonological systems, etc. See De Bot (1992) for further discussion. 
dominance. The pragmatically dominant language is the language that regulates mental processing activities in a given communicative context (and may differ depending on the context, for example, the literacy language of a bilingual community may be pragmatically dominant in argumentative formal contexts, with the oral language being pragmatically dominant in informal, conversational interactions). Note that the sociolinguistically dominant language is yet different. This latter is not always the pragmatically dominant language, which in a given communicative situation can be the sociolinguistically subordinate language. Sociolinguistic dominance can of course also be expected to influence the speakers' relative cognitive dominance at a given point in discourse. In the Paraguayan case, the pragmatically dominant language for bilinguals in non-formal, non-administrative situations is generally Guarani. ${ }^{10}$ Our definition of cognitive dominant language attempts to differentiate more clearly the different kinds of dominance, and is in fact what Matras (2000: 84) defines as pragmatic dominance:

[T] he pragmatically dominant language [is] the language which, at any given moment of discourse interaction, is granted maximum mental effort by speakers [i.e., what we call cognitive dominance]. This may be the speaker's first language, or one that is dominant for a particular domain of linguistic interaction [i.e., what we call pragmatic dominance, stricto sensu], or one that exerts pressure due to its overall role as the majority language that is culturally prestigious or economically powerful [i.e., what we call sociolinguistic dominance].11

Matras notes that pragmatically dominant languages tend to lend their discourse markers to the recipient language. Effects of the pragmatically dominant

10 Note that in the literature it is usually the more prestigious language that donates discourse markers, loanwords and structural interference. The Jopara case is interestingly unique in this regard.

11 My definitions, stemming from the reading and clarification of Matras' quote, are still rather programmatic. Evidence for what a particular speaker's cognitively dominant language is, at a specific point of discourse (which may be the same as the sociolinguistically and pragmatically dominant languages or not), is not so easy to establish. Instead there are reasonably reliable measurements of a speaker's general dominance pattern, i.e. in which of the two languages proficiency is higher. Usually, we may assume a good correspondence between a speaker's dominant language in this sense and the cognitively dominant language in that speaker's language use, but this assumption will be increasingly more problematic the more balanced the speaker's proficiencies in the two languages are and the more the speaker's language use is characterized by constant back-and-forth mixing, as is the case in many Paraguayan speech communities. 
language on the other language can in fact result synchronically from what Verschik (2010) calls a pragmatic gap, that is, speakers of a language may feel the need to express pragmatic meanings that are absent in the other language. ${ }^{12}$ In this case, the pragmatic gap would cause a planning conflict already at the conceptualization stage. Moreover, a pragmatic gap would increase the attractiveness of an item (in the sense of Johanson, 2002), as Backus and Verschik (2012) argue. Early synchronic choices can of course become diachronically conventionalized in a particular mixed lect. Clearly, at an early stage of contact, Guarani speakers would have felt very strongly the need to express certain meanings that are not conventionalized (and therefore not very strongly conceptualized) in Spanish. In the present era, one has the synchronically interacting factors of (1) still having speakers that are Guarani-dominant (in several sociolinguistic subgroups in Paraguay, e.g., rural) and, additionally, (2) having frequent or semi-conventionalized patterns of speech that include mixing that even Spanish-dominant speakers can latch onto. Hence, the production patterns of two different speakers can look similar or identical, even though there may be different factors and forces at stake for each one of them.

To summarize, I believe that careful consideration of language planning procedures is necessary to understand borrowing (and more generally code-mixing) phenomena produced by bilinguals. I assume a language planning model that starts with the emergence of a communicative intention and a subsequent conceptualization step in which a preverbal message is formed. This preverbal message is a conceptual encoding of "content-tobe-conveyed" that is already influenced by what is usually conveyed in the cognitively dominant language in that given communicative situation. For a bilingual speaker, in the course of planning the sentence in the LA/recipient language, the pressure of this conventionalized conceptual planning in the $\mathrm{LB} /$ donor language is higher the more cognitively dominant $\mathrm{LB}$ is in that context.

\section{$5 \quad$ Revisiting Guarani “Grammatical Borrowings"}

The occurrence of overt Guarani morphology in Paraguayan Spanish is an instance of what Backus and Verschik (2012) term global copying, a label they

12 Hickey (2010:155), for example, explains the emergence of a second person plural pronoun in Irish English and the co-opting of West African unu 'you.PL' in Caribbean English, from the existence of such a difference in Irish and West African languages. 
take from the Code Copying Model of Johanson (2002). Global copying occurs when the material properties of an item in LA are copied into LB, that is, when an overt form from LA occurs in LB. This contrasts with selective copying, where what is copied is the meaning of the LA form and/or its combinatorial affordances and/or its frequency of use, but crucially, not its overt form. In what follows, I will show how global copying of Guarani morphology can be explained by recourse to bilingual language planning.

In section 3.2.5 above, I showed that Guarani items with propositional or attitudinal import are high in borrowability. We know this to be generally true for other language pairs. In Matras (2009: 137), borrowability is increased for elements that "are responsible for monitoring and directing the hearer's processing of propositional content", hence prominent at the discourse level. Matras (2007:34) highlights specifically "operations that gauge the presentation of propositional content to hearer expectations." Such is the case of Guarani's emphatic markers and interrogative modalizers.

Take, for example, the emphatic veridical =niko (and its allomorphic variants $=k o /=n g o /=n i n g o)$. When Guarani-Spanish bilinguals produce Spanish utterances, their "thinking for speaking" (in Slobin's terms) at the message level makes them include the emphatic veridical meaning as part of their conceptual representation, triggered because the Guarani utterance schemas in which emphasis is part of the meaning are entrenched for them. This yields sentences in which a Guarani grammatical morpheme is attached to Spanish material, because at the functional level at which word lemmas (with syntactic but not phonological properties yet) are selected, these speakers select the emphatic markers. The competition here is between marking emphasis morphosyntactically, with an actual morpheme (the Guarani option), or marking it intonationally or not at all (the Spanish option). Widespread global copying (i.e, "borrowing") of the Guarani emphatic marker suggests that using it is the more 'attractive' option (in Johanson's, 2002, terms), perhaps because no morphemes in Spanish have a meaning or function that are judged to be similar enough to allow selective copying, while the Guarani unit is entrenched and easily activated. (In Section 6, I will discuss cases where a Spanish overt form does have a meaning that is judged "close enough" to the Guarani conceptualized meaning, especially the nominal markers -kue and -rã.) As lemma selection is proceeding, the first phrasal chunk is planned syntactically. As planning proceeds with the rest of the chunks from left to right (see in particular the incremental planning in Garrett's, 1980, model), the procedure to encode phonologically that first phrasal chunk begins. This procedure includes closing the first phrasal chunk in the clause with the selected emphatic marker. 
Note that this is contingent on the bilingual speaker recognizing enough similarity or equivalence between phrasal chunks in Spanish and in Guarani, so as to identify a phrase-final word in Spanish that the Guarani morpheme can be attached to. ${ }^{13}$ Syntactic differences between Guarani and Spanish at the level of the immediate constituents of the clause (the level at which equivalence must operate here) are minimal: the order of the sentence's major constituents, for example, is variable in both Spanish and Guarani, and subject to much the same information structure constraints (see Estigarribia, 2020). Morphosyntactic differences in the internal structure of phrases are certainly bigger, but they don't impact recognition of a sentence's "second position" in which these clitics can be produced. Morphological integration is furthermore unproblematic: the Guarani elements impose no specific lexical selection constraints, no phonotactic constraints are violated in either language. If there are no other conflicts between the Guarani and the Spanish planning, global copying in this case is an optimal way to resolve the conflict created by conceptualization of a Guarani meaning (emphatic) that is not encoded by an overt form in Spanish.

Guarani imperative modalizers are similar to emphatic veridical =niko in that they convey a kind of propositional attitude content: they serve to indicate the strength of a request or command. The fact that these meanings are grammaticalized in a morphological paradigm in Guarani serves as well to make them salient for Guarani speakers. I hypothesize that the need for indicating whether a command is merely a polite request, or a stringent order, and other mitigating meanings, is already part of a Guarani speaker's conceptualization of a directive speech act. Since Spanish does not have a dedicated set of morphemes for this function, global copying of the Guarani set of imperative modalizers can satisfy the need for expressing that function. Notably, these markers are more tightly morphosyntactically integrated in a Guarani clause than second-position clitics (i.e., emphatic veridical $=n i k o$, interrogative $=p a /=p i k o$ ), since they are wordlevel affixes that attach to the clause's main predicate. Affixal status, hence, does not seem to be a big impediment to global copying. ${ }^{14}$

An interesting case is provided by the Guarani interrogative markers. They are obligatory in Guarani interrogatives, since they are the only means to mark interrogative force in the language. However, they are not strictly necessary to convey interrogative meaning when a bilingual speaker is using Spanish, since Spanish relies on intonation. This would predict that the need for satisfying marking of

13 I thank Nikolay Hakimov for helping me clarify this point.

14 And, of course, there are attested cases of affix borrowing in the literature. 
interrogative force would be met with Spanish prosodic means. Moreover, Matras (2007) also notes that borrowing of question particles is rare, and the only case he finds is the replacement in Macedonian Turkish of the Turkish interrogative particle with the Albanian one (Matras and Tufan, 2007). All this would make borrowing of Guarani interrogative second-position clitics unlikely. ${ }^{15}$ The fact that Guarani interrogative markers are indeed used in Paraguayan Spanish is consistent with the contention that Guarani is for many speakers the cognitively dominant language in informal language use, and that therefore it strongly constrains these Guarani speakers to mark the illocutionary force of an utterance following Guarani planning procedures. A perhaps more tempting hypothesis is that this dominance was the case for early generations of speakers who would have been much less proficient in Spanish, and that their patterns of use of Guarani morphemes in Spanish discourse became reproduced and conventionalized through regular transmission of Jopara patterns. ${ }^{16}$

Another factor that favors borrowing in this case is that the Guarani markers are independent lemmas and as such, they are salient to speakers. Lemmas are presumably highly salient in general: in fact, usage of a question particle is by far the most common means of marking polar questions cross-linguistically ( 585 out of the 955 languages sampled in Dryer, 2013). If we view grammatical constructions on a cline from phonologically fully specified constructions to completely schematic constructions, we can hypothesize that phonologically specific constructions would be selected because they are more salient and accessible to the speaker than phonologically empty, purely combinatorial Spanish constructions. ${ }^{17}$ Additionally, interrogative clitics do not impose any lexical selection (they attach to any word that ends the first phrase in the sentence, usually its focus): this also facilitates their borrowing. Illocutionary force is furthermore preferably marked lexically: it is highlighted and included in the initial conceptual representation and satisfied at the very early level of lemma selection. Finally, the Guarani planning procedure does not interfere with any other Spanish procedures: the prosodic planning procedure that marks questions in Spanish need not be suppressed and can be followed at the same time as the Guarani lemma selection procedure.

15 Even more unlikely when one considers that whereas the Albanian interrogatives appear in lieu of Turkish interrogatives, benefitting from categorial (although not linear) equivalence, the second-position interrogative clitics of Guarani have no categorial (and a fortiori, no linear) equivalent.

16 I thank Ad Backus for helping me clarify this point.

17 I thank Nikolay Hakimov for discussion of this point. 
This planning scenario holds when the LB/donor language grammatical items do not have parallels/equivalents in the LA/recipient language, as we have seen so far, but also when they do. For example, the intensifier -ete (with no Spanish close categorial equivalent) or the nominal tense -kue (with a Spanish close equivalent, see section 6) are used in Paraguayan Spanish because they often figure in conceptualizations of events in Guarani discourse, perhaps more so than in conceptualizations of events in Spanish discourse (this is an impressionistic observation, and of course a corpus or experimental study would be needed to verify it). The Guarani speaker can also be somewhat predisposed to conceptualize salient distinctions that the L1 makes, or the community focuses on (cf. the notion of discursive relativity in Lucy, 1996), ultimately relying on the entrenchment of these form-meaning units in the speakers' mental representations.

I conclude this section by noting that, in other cases where there are planning conflicts, this may hinder borrowing, or perhaps in rare instances yield "doubling" outcomes. A case where planning conflicts are a possible explanation for observed doubling patterns is that of the borrowing of Guarani postpositions. There are many examples of this in the bilingual novel Ramona Quebranto (Ayala de Michelagnoli, 1989), but only one attested case in the movie Siete Cajas (27) and none at all in the naturalistic data coming from social media.

$\begin{array}{lllll}¿ Y \quad \text { dónde=pe } \quad(\text { es)tá } & \text { tu } & \text { amigo? } \\ \text { and } \quad \text { where=LOC is } & \text { your } & \text { friend } \\ \text { 'And where is your friend?' }\left[{ }_{7} \mathrm{C}\right] & & \end{array}$

Like interrogatives and emphatics, the postpositions are phrasal clitics, so their morphosyntax alone cannot explain the lack of extensive borrowing in this case. It is true that the postpositions' meaning is not discourse-marker-like or propositional, but rather truth-conditional, and therefore their borrowing is not necessarily expected. But I surmise that the most important factor against such borrowings is that they induce a planning conflict between Spanish and Guarani. The semantic content of (Spanish) pre- and (Guarani) postpositions is selected at the conceptualization level and perhaps both the Spanish and the Guarani associated lemmas are activated at the formulation/lemma selection stage. But at the stage of planning of the corresponding phrasal chunk, the planning procedure for Spanish requires beginning the phrasal chunk with a prepositional lemma (planning a prepositional phrase), whereas that from Guarani requires beginning with a noun phrase and ending with a postpositional lemma (planning a postpositional phrase). This conflict can logically be 
resolved in three ways: the Guarani postpositional planning is suppressed and the postpositional lemma abandoned (blocking or pre-emption of the Guarani lemma); the Spanish prepositional planning is suppressed and its associated lemma abandoned (blocking or pre-emption of the Spanish lemma); or both planning procedures are applied and yield surface "doubling". The first option is the only one attested in naturalistic data; the second is attested in the novel, but this may not reflect actual practice (more fieldwork is needed to answer this question); the last option is, to my knowledge, only attested in Jopara with the doubling of Spanish $y a$ and Guarani - $m a$ (see Estigarribia, 2020: 163). ${ }^{18}$

\section{$6 \quad$ Selective Copying and Construal of Equivalence}

Guarani borrowed interrogative markers, emphatic markers, and imperative modalizers have no categorial equivalents in Spanish. The postpositions have semantic equivalents but no linear equivalents. Interestingly, Guarani has another emphatic morpheme, voi, which conveys an emphatic assertion of an action (28a), and often functions as a marker of epistemic modality, namely speaker's certainty $(28 \mathrm{~b})$.

(28a) Omba'apo voi.

o-mba'apo=voi

3.ACT-work=CERT

'He works with dedication.'

(28b) Iporã voi.

i-porã =voi

3.INACT-beautiful $=$ CERT

'It is certainly beautiful.' (https://es.wikibooks.org/wiki/Guaran $\% \mathrm{C}_{3} \% \mathrm{AD} / \mathrm{Gram} \% \mathrm{C}_{3} \%$ A1tica/Determinantes_intensivos.)

Even though this marker is part of the emphatic marker paradigm together with niko, it hasn't been borrowed in Spanish. This is likely because even though voi does not have an equivalent morpheme in Spanish, speakers can

18 This doubling is cross-linguistically not very common, at least not as the dominant option. Numerous examples are found in the literature, however (see Muysken, 2000: 104-105), for example with the plural in Finnish-English contact (Halmari, 1997), and with conventionalized double adpositions in Kurdish-Turkish contact (Ad Backus, p.c.). 
recruit another unit that is perceived as similar. That is, instead of viewing equivalence as a fixed quantity, determined solely by the formal/meaning properties of language units, we can adopt Sebba's (1998) perspective that equivalence is created by speakers. As Jarvis and Pavlenko (2008: 179) put it, "[a] perceived similarity is a conscious or unconscious judgment that a form, structure, meaning, function, or pattern that an L2 user has encountered in the input of the recipient language is similar to a corresponding feature of the source language". Speakers do not only perceive but can also coerce similar units to become equivalent..$^{19}$ For example, if the $\mathrm{LB} /$ donor language has a particle whose usage is similar enough to a particle or other kind of marker in the LA/recipient language, then the LB particle can be borrowed. Alternatively, the $\mathrm{LB} /$ donor language can have a form for a meaning that does not have a ready-made, accessible form in the LA/recipient language, and then speakers can co-opt a form with a meaning that is close. To render the Guarani emphatic voi, Paraguayan speakers use luego 'after, hence' (often phonologically reduced to loo (29). Luego in Spanish is an adverb with the temporal meaning 'after, later', but also a conjunction with the meaning 'therefore, thus'. I surmise that Guarani speakers may have judged this latter meaning to be similar enough or coercible enough to fulfill the functions of voi, therefore eschewing global copying in favor of a selective copying solution. The adoption of a consecutive marker as an emphatic marker seems plausible from a pragmatic point of view, and has been attested, for example, in the borrowing of Italian dunque 'thus' into Italo-Greek with a range of meanings that include emphatic questions and emphatic imperatives (see Stolz, 2007).

$\begin{array}{llll}\text { (29) } \begin{array}{l}\text { Quérico loo } \\ \text { how delicious then }\end{array} & \text { es } & \text { mi } & \text { sánguche... } \\ \text { 'My sandwich is so delicious...' }{ }^{[7 C]} & & & \end{array}$

I believe the same explanation is likely in the case of the suffixal nominal tense/ aspect markers -kUe 'PAST TENSE/POST-STATIVE ASPECT' and -rã 'FUTURE TENSE/DESTINATIVE ASPECT' (see Tonhauser, 2007; Estigarribia, 2017b, 2020; Gynan, 2017). The former marks the base noun as denoting a property that has ceased to be at the time of interpretation of the noun phrase (30), and the latter that an individual will have the property the base noun denotes in the future (31). Whereas the past marker -kue is indeed used in Paraguayan Spanish

I thank Ad Backus for discussion of this point. 
(global copying; see 32) speakers use Sp. para 'for' to render the meaning of future nominal -rã (selective copying, 33).

(30) che-róga-kue

1SG.INACT-house-POST

'my former house' (i.e., because I don't own it anymore, or I don't live there, or it is not a house anymore) (Estigarribia, 2017b: 35)

(31) che-róga-rã

1SG.INACT-house-DEST

'my future house' (i.e., one I will live in or in reference to the materials to build my house) (Estigarribia, 2017b: 36)

(32) enero se resiste, parece novio kue

enero se resiste parece novio-kue

January resists it.seems boyfriend-POsT

'January refuses to leave, it resembles an ex-boyfriend'20 (Estigarribia, 2017c: 339)

(33) vos

you.2SG be.2SG for my girlfriend

'You are my future girlfriend' (Velázquez-Castillo and Henderson, 2013: 84)

Velázquez-Castillo and Henderson (2013) explain these idiosyncratic uses of Sp. para as instances of grammatical replication (Heine and Kuteva, 2005), which involves creating in the recipient language an equivalent category to one found in the donor language but using material from the recipient language. What is important here is that the Guarani markers are required in contexts were Spanish has no special NP marking or other treatment. For example, in (34a), the deverbal nominalization rembiu is suffixed with DESTINATIVE -rã because the food the speakers will buy for themselves, and that will come into their possession as a result, is not their food at the moment of utterance,

20 http://es.twtrland.com/profile/claudioalcides, accessed 11 February 2016. 
so it would be strictly speaking incorrect to call it ore rembi'u 'our food'. The same is true in $(34 \mathrm{~b})$ : the speakers are planning to find themselves a friend, and that person is not currently a friend of theirs, so it cannot be referred to as ñane irũ 'our friend': Jaha jaheka ñane irũ (without -rã) would mean that the speakers are planning to go look for a specific current friend. VelázquezCastillo and Henderson call these contexts of use anticipated possession. One can see why this would be an important aspect of the conceptualized message for a Guarani speaker: it is simply a very salient distinction that needs to be morphologically marked. At the same time, Sp. para is a preposition which relates a NP to a predicate, and its normative uses are often telic (focusing on the endpoint of a relation between two entities) and express an intended benefactive (35). Both of these, Velázquez-Castillo and Henderson argue, support an extension of its use to cover prospectivity in the nominal domain. Hence, here I conclude that Guarani speakers conceptualize anticipated possession/ prospectivity as part of the intended message and that they also coerce para to fulfill this function, yielding an instance of selective copying.

(34a) Rojoguase ore rembiurũ.

Ro-jogua-se
1PL.EXCL.ACT-buy-DES

ore-r-embi-'u-rã

1PL.EXCL.INACT-POSSM-NMLZ.TR-eat-DEST

'We want to buy something to eat (for us)' (Lustig, 2005: 67)

(34b) Jahajaheka ñane irũrã.

Ja-ha ja-heka ñane-irũ-rã

1PL.INCL.ACT-go 1PL.INCL.ACT-seek 1PL.INCL.INACT-friend-DEST

'Let's go look for a friend for us' (Tonhauser, 2007: 836)

$\begin{array}{llllll}\text { Compro } & \text { una } & \text { torta } & \text { para } & \text { mi } & \text { mamá. } \\ \text { I.buy } & \text { one } & \text { cake } & \text { for } & \text { my } & \text { mom }\end{array}$

'I am buying a cake for my mom.'

To close this section, it is important to note that, in most cases, this selective copying/coercion option seems not to have been taken. It is difficult to explain why in a deterministic fashion. One factor militating against selective copying may be the result of the rather substantial morphosyntactic differences between Guarani and Spanish, and relatedly, the fact that speakers may not be able to coerce Spanish units to express most of the Guarani morphologized 
meanings we have discussed. Additionally, I believe that another crucial factor in this explanation is the prolonged period of coexistence and extended bilingualism (albeit imperfect in many cases) in Paraguay. As a result, global copying in both directions is extensive, and is likely to have been favored by the lack of a Guarani norm until very recently, and by the low impact of the Spanish norm in Paraguay, especially due to the demographic and historical reasons mentioned above in section 2 .

\section{$7 \quad$ Conclusion}

In this paper, I have examined the well-known phenomenon of Guarani "grammatical borrowings" in colloquial Paraguayan Spanish. Perhaps the most immediate contribution of this work is to broaden the spectrum of language contact data that can be used to build and test theory. We must first note that Guarani, despite its unquestionable importance as the only indigenous language of the Americas that is widely spoken by non-indigenous populations (about 7 million speakers), is relatively understudied, especially compared to language families like Quechua or Mayan. Guarani's singular circumstances raise pivotal questions about language planning and language survival in postcolonial settings, the role and maintenance of an indigenous language in the constitution of a hybrid identity, and most relevantly here, the impact specific sociohistorical situations have on the structural outcomes of prolonged language contact. In regards to this, I have provided data on contact that go against some well know frequent patterns. The common situation with grammatical/DM borrowing is that of a colonial/dominant language exerting pressure on the indigenous language (Matras, 1998) and imposing their particles on it. In this case, a more common scenario in Spanish contact varieties is that of the use of Spanish forms to render evidential meanings (for example) that are felt to be needed and lacking in Spanish, by speakers of indigenous languages that have those categories. A well-known case is that of Spanish DM s such as pues 'well', nomás 'just', pero 'but', and verb forms such as dice 'says' and habia sido 'it used to be', that appear in Quechua and Aymara with functions similar to these languages' suffixes conveying mirativity, evidentiality, or more generally degrees of speaker involvement. What is different in the Guarani case is the use of the actual indigenous language markers in colonial language discourse. This is the opposite scenario to the more common one: in Paraguay, the indigenous language, Guarani, exerts planning pressure on the colonial/dominant language, Spanish. A more in-depth analysis of the current sociolinguistic 
situation in Paraguay can shed light on why this is the case, but it falls outside of the scope of this paper. In any case, sociolinguistic considerations alone cannot explain the intricate ways in which certain markers are adopted while others are not. For that, one must augment our understanding of the broader sociolinguistic factors at play with an understanding of the processing issues partially but not fully determined by sociolinguistic choices such as identity construction, prestige, etc. In the end, a model is needed where broader sociolinguistic factors contribute to determine more specific things such as which language is sociolinguistically, pragmatically, and/or cognitively dominant in a given interaction for a group of speakers, and in turn, these progressively "narrower" factors determine the extent of specific formal choices these speakers have.

Hence, another way in which this work contributes to our understanding of language contact is by understanding static notions of linguistic description, such as morphosyntactic (in)dependence, equivalence or frequency, as abstract outcomes of the processes that go on in the minds of speakers whenever they produce language. Once understood this way, these notions do have a role in explaining language mixing, but I believe they are ultimately incomplete without an understanding of how planning figures in the equation. Specifically, in the cases examined here, the notion of cognitively-dominant language, and related ones such as macro- and microplanning, conceptual transfer, and pragmatic gap are useful to help us explain how careful consideration of bilingual planning procedures for production illuminate borrowing/Cs outcomes in language contact.

To conclude, my analysis of the incorporation of Guarani grammatical morphemes with primarily pragmatic meanings into Paraguayan varieties of Spanish links up with a general usage-based view of the mental representation of linguistic knowledge and the way in which this representation affects language production. The latter point is crucial. The borrowing of grammatical morphemes, albeit cross-linguistically rare, makes sense in this particular case: bilingual speakers of Guarani in the specific sociolinguistic setting of bilingual Paraguay, with its facilitation of continuing Guarani proficiency, were and are in a situation where entrenched pragmatic form-meaning units can influence utterance planning in otherwise Spanish language use, and lead to their activation of these units when there are no obvious Spanish equivalents blocking their selection. It is difficult to see how this can be accounted for without usage-based concepts such as entrenchment and salience. 


\section{Acknowledgements}

I would like to thank the editors of this special issue, Ad Backus and Nikolay Hakimov, for fruitful discussion of many of the topics in the paper. I am responsible for all inaccuracies and errors of interpretation that may remain.

\section{Appendix with abbreviations not included in the Leipzig conventional list}

A Spanish "personal $a$ " (differential object marking for animate specific direct objects)

ACT Active person marker

CERT Speaker certainty

DEST Destinative aspect

DIM Diminutive

FORCE Forceful imperative

INACT Inactive person marker

MIT Mitigative imperative

NMLZ.TR Transitive nominalizer

POSSM Possessum form for when possessor is not 3 person pronominal

POST Post-stative aspect

REQ Requestative

SE Spanish se clitic (middle voice or deagentivizer/intransitivizer)

URG Urging imperative

VERD Veridical emphatic

\section{References}

Ayala de Michelagnoli, Margot. 1989. Ramona Quebranto. Asunción, Paraguay: Editorial Arandurã.

Ayala, José Valentín. 1996. Gramática guaraní. Buenos Aires: Ministerio de Cultura y Educación de la Nacion, Republica Argentina.

Backus, Ad and Anna Verschik. 2012. Copiability of (bound) morphology. In Lars Johanson and Martine Robbeets (eds.), Copies versus cognates in bound morphology, 123-49. Leiden: Brill. 
Corvalán, Graziella. 1990. La realidad social y lingüística de Asunción. Revista Paraguaya de Sociología 27: 89-116.

De Bot, Kees. 1992. A Bilingual Production Model: Levelt's “Speaking” Model Approach. Applied Linguistics 13 (1): 1-24.

Dryer, Matthew S. 2013. Polar questions. In Matthew S. Dryer and Martin Haspelmath (ed.), The world atlas of language structures online, n.p. Leipzig: Max Planck Institute for Evolutionary Anthropology. Retrieved from http://wals.info/chapter/116.

Estigarribia, Bruno. 2015. Guaraní-Spanish jopara mixing in a Paraguayan novel: Does it reflect a third language, a language variety, or true codeswitching? Journal of Language Contact 8 (2): 183-222.

Estigarribia, Bruno. 2017a. Guarani morphology in Paraguayan Spanish: insights from code-mixing typology. Hispania 100 (1): 47-64.

Estigarribia, Bruno. 2017b. A grammar sketch of Paraguayan Guarani. In Bruno Estigarribia and Justin Pinta (eds.), Guarani Linguistics in the 21st Century, 7-85. Leiden, Netherlands: Brill.

Estigarribia, Bruno. 2017c. Insertion and backflagging as mixing strategies underlying Guarani-Spanish mixed words. In Bruno Estigarribia and Justin Pinta (eds.), Guarani Linguistics in the 21st Century, 315-347. Leiden, Netherlands: Brill.

Estigarribia, Bruno. 2020. A Grammar of Paraguayan Guarani. Grammars of World and Minority Languages Series. London: UCL Press.

Garrett, Merrill F. 1980. Levels of processing in sentence production. In Brian Butterworth (ed.), Language Production (Volume 1), 176-220. Orlando, FL:Academic Press.

Gómez Rendón, Jorge A. 2008. Typological and social constraints on language contact: Amerindian languages in contact with Spanish. Utrecht: LOT.

Gómez Rendón, Jorge A. 2017. The Demographics of Colonization in Paraguay and the Emergence of Paraguayan Guarani. In Bruno Estigarribia and Justin Pinta (eds.), Guarani Linguistics in the 21st Century, 131-57. Leiden, Netherlands: Brill.

Granda, Germán de. 1980. Préstamos morfológicos del guaraní en el español del Paraguay (I) Revue de Linguistique Romane 44: 57-68.

Granda, Germán De. 1996. Interferencia y convergencia sintácticas e isogramatismo amplio en el español paraguayo. International Journal of the Sociology of Language 117: $63-8$ o.

Guarania, Félix de. 2008. Tabla sinóptica para una nueva gramatica guarani (2nd ed.). Asunción, Paraguay: Servilibro.

Gynan, Shaw N. 2017. Morphological glossing conventions for the representation of Paraguayan Guaraní. In Bruno Estigarribia and Justin Pinta (eds.), Guarani Linguistics in the 21st Century, 86-130. Leiden, Netherlands: Brill.

Hill, Jane H., and Kenneth C. Hill. 1986. Speaking Mexicano: Dynamics of Syncretic Language in Central Mexico. Tucson, AR: The University of Arizona Press. 
Krivoshein de Canese, Natalia, and Feliciano Acosta Alcaraz. 2007. Gramática guaraní. Asunción: Instituto Superior de Lenguas, Universidad Nacional de Asunción.

Krivoshein de Canese, Natalia, and Grazziella Corvalán. 1987. El español del Paraguay: en contacto con el guaraní. Asunción: Centro Paraguayo de Estudios Sociológicos.

Halmari, Helena. 1997. Government and codeswitching: Explaining American Finnish. Amsterdam: John Benjamins.

Heine, Bernd, and Tania Kuteva. 2005. Language Contact and Grammatical Change (Cambridge Approaches to Language Contact). Cambridge: Cambridge University Press.

Hickey, Raymond. 2010. Contact and language shift. In Raymond Hickey (ed.), The Handbook of Language Contact, 151-69. Oxford: Wiley-Blackwell.

Jarvis, Scott. 2007. Theoretical and methodological issues in the investigation of conceptual transfer. In Vigo International Journal of Applied Linguistics 4 (special issue "Current Issues in Second Language Acquisition", edited by Rosa Alonso and Marta Dahlgren), 43-71. Vigo: Servicio de Publicacións da Universidade de Vigo.

Jarvis, Scott. 2011. Conceptual transfer: Crosslinguistic effects in categorization and construal. Bilingualism: Language and Cognition 14 (1): 1-8.

Jarvis, Scott and Aneta Pavlenko. 2008. Crosslinguistic Influence in Language and Cognition. New York, NY: Routledge.

Johanson, Lars. 2002. Structural Factors in Turkic Language Contacts. London: Curzon. Kleinpenning, Jan M. G. 2011. Paraguay 1515-1870. Una geografía temática de su desarrollo. Asunción: Editorial Tiempo de Historia.

Levelt, Willem J. M. 1989. Speaking: From Intention to Articulation. Cambridge, MA: MIT Press.

Lucy, John A. 1996. The scope of linguistic relativity: an analysis and review of empirical research. In John J. Gumperz and Stephen C. Levinson (eds.), Rethinking Linguistic Relativity, 37-69. Cambridge. MA: Cambridge University Press.

Lustig, Wolf. 2005. Guarani Wort für Wort (2nd ed.). Bielefeld: Peter Rump GmbH.

Maneglia, Juan Carlos and Tana Schembori. 2014. 7 Boxes. Film: Action, Thriller.

Matras, Yaron. 1998. Utterance modifiers and universals of grammatical borrowing. Linguistics 36 (2): 281-331.

Matras, Yaron. 200o. Mixed languages: a functional-communicative approach. Bilingualism: Language and Cognition 3 (2): 79-99.

Matras, Yaron. 2007. The borrowability of structural categories. In Yaron Matras and Jeanette Sakel (eds.), Grammatical borrowing in cross-linguistic perspective, 31-74. New York: Mouton de Gruyter.

Matras, Yaron. 20og. Language Contact. Cambridge: Cambridge University Press.

Matras, Yaron and Şirin Tufan. 2007. Grammatical borrowing in Macedonian Turkish. InYaron Matras and Jeanette Sakel (eds.), Grammatical borrowing in cross-linguistic perspective, 215-227. New York: Mouton de Gruyter. 
Melià, Bartomeu. 1986. El Guaraní - conquistado y reducido: ensayos de etnohistoria.. Asunción: Centro de Estudios Antropológicos, Universidad Católica.

Muysken, Pieter. 200o. Bilingual Speech. Cambridge: Cambridge University Press.

Ortiz, Diego, Domingo Aguilera and Elda Marecos. 1991. Hablemos el guaraní: curso completo en cuatro niveles para extranjeros (Volume 1). Asunción: CEPAG (Centro de Estudios Paraguayos "Antonio Guasch").

Palacios Alcaine, Azucena. 1999. Introducción a la lengua y cultura guaraníes. Valencia: Universitat de València, Departament de Teoria dels Llenguatges.

Penner, Hedy, Soledad Acosta, and Malvina Segovia. 2012. El descubrimiento del castellano paraguayo a través del Guaraní: Una historia de los enfoques lingüísticos. Asunción: Universidad Católica Nuestra Señora de la Asunción.

Sebba, Mark. 1998. A congruence approach to the syntax of codeswitching. International Journal of Bilingualism 2 (1): 1-19.

Slobin, Dan I. 1996. From "Thought and language" to "Thinking for speaking". In John J. Gumperz and Stephen C. Levinson (eds.), Rethinking Linguistic Relativity, 70-96. Cambridge, MA: Cambridge University Press.

Stolz, Thomas. 2007. Allora: On the recurrence of function-word borrowing in contact situations with Italian as a donor language. In Jochen Rehbein, Christiane Hohenstein, and Lukas Pietsch (eds.), Connectivity in Grammar and Discourse, 75-10o. Amsterdam: John Benjamins.

Tonhauser, Judith. 2006. The temporal semantics of noun phrases: Evidence from Guaraní. PhD diss., Stanford University. Retrieved from http://www.ling.ohio-state. edu/ judith/tonhauser-dissertation.pdf.

Tonhauser, Judith. 2007. Nominal tense? The meaning of Guaraní nominal temporal markers. Language 83 (4): 831-69.

Torres, Lourdes. 2006. Bilingual discourse markers in indigenous languages. International Journal of Bilingual Education and Bilingualism 9 (5): 615-624, DOI: $10.2167 /$ beb383.o.

Usher de Herreros, Beatriz. 1976. Castellano paraguayo: notas para una gramática contrastiva castellano-guaraní. Asunción: Centro de Estudios Antropológicos Universidad Católica "Nuestra Señora de la Asunción."

Velázquez-Castillo, Maura. 2004. Guaraní (Tupí-Guaraní). In Geert E. Booij, Christian Lehmann, Joachim Mugdan, and Stavros Skopeteas (eds.), Morphology: An international handbook on inflection and word-formation (Volume 2), 20oo. Berlin, New York: Walter de Gruyter.

Velázquez-Castillo, Maura. 2008. Voice and transitivity in Guaraní. In Mark Donohue and Søren Wichmann (eds.), The typology of semantic alignment, 380-95. Oxford: Oxford University Press.

Velázquez-Castillo, Maura, and Mary Hudgens Henderson. 2013. Quiero para mi novio: Aspectual uses of para in Paraguayan Spanish. Journal of Pidgin and Creole Languages 28 (1): 65-102. 
Verschik, Anna. 2010. Ethnolect debate: Evidence from Jewish Lithuanian. International Journal of Multilingualism 7 (4): 285-305.

von Stutterheim, Christiane, and Ralf Nüse. 2003. Processes of conceptualization in language production: Language-specific perspectives and event construal. Linguistics 41 (5): 851-81.

Zajícová, Lenka. 2009. El bilingüismo paraguayo: usos y actitudes hacia el guaraní y el castellano. Madrid: Iberoamericana.

Zarratea, Tadeo. 2002. Gramática elemental de la lengua guaraní. Asunción: Marben. 